\title{
FERRONIOBIUM ALLOY FINES AGGLOMERATION THROUGH BRIQUETTING
}

\author{
André Carlos Silva ' \\ Mariana Rezende de Barros ${ }^{2}$ \\ Kléber Silva Macedo ${ }^{3}$ \\ Elenice Maria Schons Silva'
}

\begin{abstract}
Brazil is the largest producer of Niobium alloys, with a production of 58,000 tons of $\mathrm{Nb}_{2} \mathrm{O}_{5}$ concentrate in 2016, corresponding to a $92.81 \%$ of the world production. The Brazilian Niobium ores grades vary from $0.5 \mathrm{I}$ to $2.71 \%$. Ferroniobium (Fe- $\mathrm{Nb}$ ) is an iron niobium alloy with niobium content of $60-70 \%$. It is the main source for niobium alloying of HSLA steel and covers more than $80 \%$ of the worldwide niobium production. In 20I4, Brazil produced 5 I,737 tons of $\mathrm{Fe}-\mathrm{Nb}$, being around $90 \%$ of it for exportation. In the final stage of the $\mathrm{Fe}-\mathrm{Nb}$ production, the alloy needs to be crushed in a jaw crusher, which generate fine particles (around $26 \%$ of the feed below $10 \mathrm{~mm}$ at Niobras/CMOC). The selling price of the fine particles have a significant loss in the market, since the fine particles cannot be used directly in steelmaking. A process to agglomerate the $\mathrm{Fe}-\mathrm{Nb}$ fine particles into briquettes with size and chemical composition similar to original products was developed. Organic binders were used as well as a lubricant agent. The briquettes were characterized both physically and chemically. For the physical characterization, the briquettes were tested for mechanical and water resistance, thermal shock and Brinell hardness. Briquettes containing addition of $3 \%$ of zinc stearate, $2 \%$ of iron powder, and I\% of water reached a Niobium content above $62 \%$ and contaminants levels of below the standard Fe-Nb specifications. The results indicate that Fe- $\mathrm{Nb}$ alloy fines can be technically and economically agglomerate by briquetting.
\end{abstract}

Keywords: Ferroniobium; Fines; Briquetting; Agglomeration.

\section{INTRODUCTION}

According to Mendes [ $I]$ Niobium is a trace element present in Earth crust with average grades between 0.3 and $\mathrm{I} .0 \%$ of $\mathrm{Nb}_{2} \mathrm{O}_{5}$. However, some Brazilian deposits can reach exceptional grades around $3.0 \%$ due to supergene enrichment in weathered zones. It is a metallic, soft, ductile solid and has a high melting point $\left(2,469^{\circ} \mathrm{C}\right)$ one of the highest of the periodical table. It is resistant to corrosion, mainly due to the formation of a thin film in the oxide surface, called passivation layer. It exhibit different oxidation numbers when combined, being +5 the most common. It do not react with hydrogen, air, water or acids at room temperature, except for hydrofluoric acid and its mix with nitric acid [2]. Its industrial applications include, but are not limited to, high-strength low-alloy steel (HSLA), stainless steel and super alloys. Its consumption in micro alloyed structural steels reaches above $80 \%$ of its demand [3].

Brazil holds the largest deposits Niobium in the world, distributed between the states of Minas Gerais, Amazonas, Goiás and Rondônia, with a total reserve around $10.8 \mathrm{Mt}$ of pyrochlor exploitable reserves. Brazil is also the most important producer with an annual production around 88.8 ktons of $\mathrm{Nb}_{2} \mathrm{O}_{5}$ concentrate and 51.7 ktons of $\mathrm{Fe}-\mathrm{Nb}$ alloy, with $\mathrm{Nb}$ content ranging from 60 to $70 \%$. Canada holds the second position in the world marketing with approximately a reserve of 200 ktons and annual production around 5 ktons [4]. Figure I shows Brazilian's Niobium production between the years 2000 and 20I4. It is possible to see a development in the Niobium marketing until 2010, when the steel marketing started to face a severe economic crisis. An improvement in the marketing was noticed after 2012 and 2014 end up being, together with 2009, the years with higher production in the period.

In 2017 the world's production of Fe-Nb was I 24.200 tpy, been the largest players CBMM (100.000 tpy), Niobras (I3.700 tpy), Niobec (9.000 tpy), and Taboca (I,500 tpy) [5]. Niobras is company from the Chinese group $\mathrm{CMOC}$ and is one of the three Brazilian companies that produce Fe-Nb. Situated in the state of Goiás, the company production is destined to exportation. After the aluminothermy, which is the final stage of the $\mathrm{Fe}-\mathrm{Nb}$ production, the freshly produced

\footnotetext{
'Laboratório de Modelamento e Pesquisa em Processamento Mineral - LaMPPMin, Faculdade de Engenharia, Universidade Federal de Goiás - UFG, Catalão, GO, Brasil. E-mail: ancarsil@ufg.br

${ }^{2}$ Universidade Federal de Goiás - UFG, Catalão, GO, Brasil.

${ }^{3}$ Niobras / CMOC International Brasil, Catalão, GO, Brasil.
}

2I 76-I523 (c) 2019 Associação Brasileira de Metalurgia, Materiais e Mineração. Published by ABM. This is an open access paper, published under the Creative Commons CC BY-NC-ND license (Attribution-NonCommercial-NoDerivs) - https://creativecommons.org/licenses/ by-nc-nd/4.0/. 
alloy is grinded using a jaw crusher (see Figure 2). This stage generate particles under $10 \mathrm{~mm}$, considered fine particles and not able to be used direct in the steelmaking process because only of their size. Other operations that generate fine particles are Fe-Nb screening and handling (especially the commutation between conveyor belts).

The total amount of fines produced can reach approximately 95 tons per month (equivalent to $26 \%$ of the total $\mathrm{Fe}-\mathrm{Nb}$ production). Fe- $\mathrm{Nb}$ fine particles were divided in three different classes according to their granulometry and generation process: under $2 \mathrm{~mm}$ (type A), between I and $5 \mathrm{~mm}$ (type B) and between 3 and $15 \mathrm{~mm}$ (type $\mathrm{C}$ ). Figure 3 shows samples of the three types of fines.

The agglomeration process aim in produce material with size adequate to the future application and the correct choose between the available methods depends on a very

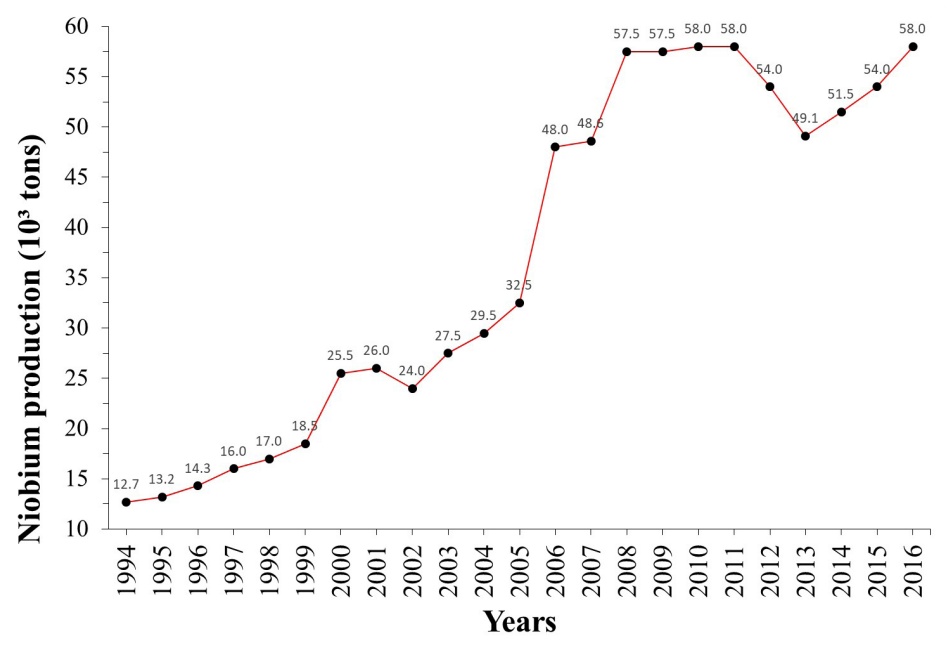

Figure I. Brazilian's Niobium production (1994-2016) [4].
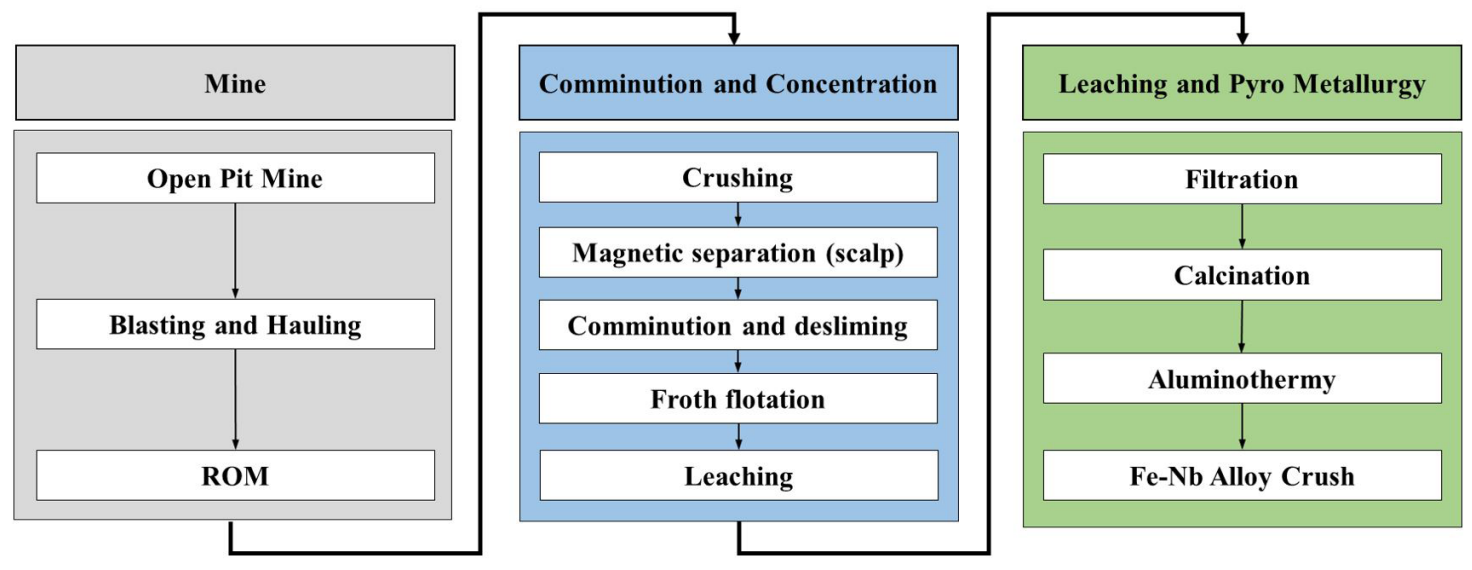

Figure 2. Fe-Nb alloy production flowsheet.

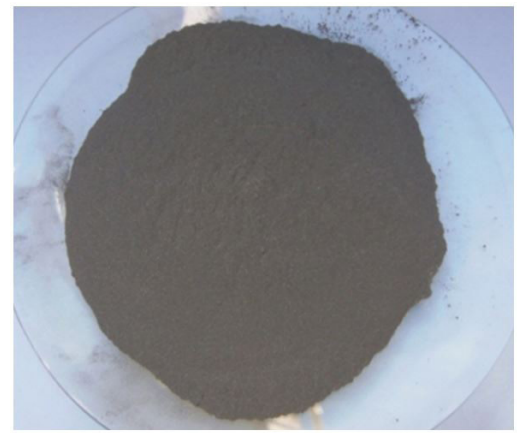

(a)

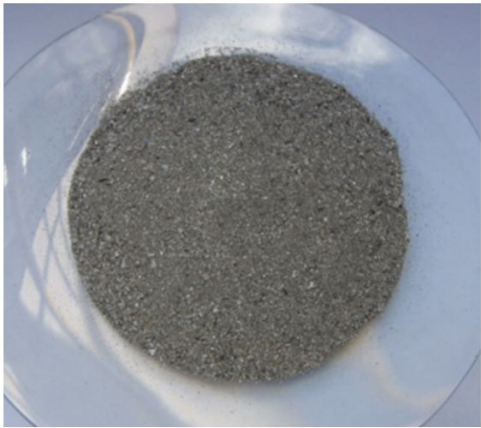

(b)

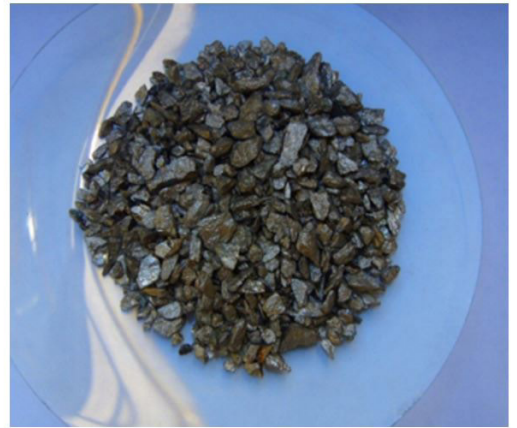

(c)

Figure 3. Fe-Nb fine particles: (a) under $2 \mathrm{~mm}$ (or type A), (b) between I and $5 \mathrm{~mm}$ or type B and (c) between 3 and $15 \mathrm{~mm}$ or type C. 
careful analyses. According to Carvalho and Brinck [6], this involves not only laboratory work in order to produce the agglomerate, but also its physical and chemical characterization. Among the agglomeration techniques, the most important ones in mineral processing are pelleting, sintering and briquetting. Some important work were performed in this field, such as Moraes and Kawatra [7], which tested how binders successfully used in the pelletizing of Brazilian hematitic iron ores, using disk pelletizer, would perform in the processing of an American magnetite concentrate by balling drums. Although the results were very good, the operational cost of the pelleting was relatively high when compared with the other two methods. Telles et al. [8] developed a sintering process to agglomerate electric arc furnaces dust in order to recycle this material in the steelmaking. In their process, the dust had to be first agglomerated as micro-pellets and then sintered. Lucena et al. [9] were able to produce a low-cost charcoal wastes briquetted to be used in blast furnaces and for energy generation using a piston extruder. On the other hand, Silva et al. [10] were able to agglomerate limestone fines using a batch briquetting process. In both case the operational cost where small.

Taking in consideration the fact that the Fe- $\mathrm{Nb}$ fine particles has very small moisture content, high melting point $\left(1,900^{\circ} \mathrm{C}\right)$ and is very abrasive the briquetting was choose as the most feasible technique to agglomerate the fine particles.

\section{METHODOLOGY}

\section{I Briquettes Production}

Samples of the $\mathrm{Fe}-\mathrm{Nb}$ fines produced from gridding, screening, and handling were sent to two different companies in Brazil to be agglomerated (Höganäs and Renova). Höganäs used a piston extruder and Renova a high-pressure roll press. Each company produced two different briquettes composed by a blend of the fine particles type composition (see Table I). The briquettes were labelled as $\mathrm{H}$ (for Höganäs) and $\mathrm{R}$ (for Renova) followed by the percentage of the fines on it. The main differences in the two processes were the manufacture costs and briquettes geometry.

The organic binders used were zinc stearate $\left(\mathrm{Zn}\left(\mathrm{C}_{18} \mathrm{H}_{35} \mathrm{O}_{2}\right)_{2}\right)$ and zinc palmitate $\left(\mathrm{Zn}\left(\mathrm{C}_{16} \mathrm{H}_{31} \mathrm{O}_{2}\right)_{2}\right)$ in a proportion of 70 and $30 \%$ respectively. Iron powder with very low impurities grade was used as lubricant. The proportion, in weight, of addictions was $3 \%$ of binder, $2 \%$ of iron powder, and $1 \%$ of water. The homogenization

Table I. Briquettes composition regarding the fine particles type

\begin{tabular}{lccc}
\hline \multicolumn{1}{c}{ Briquettes } & A & B & C \\
\hline RI00-0-0 & 100 & 0 & 0 \\
R0-100-0 & 0 & 100 & 0 \\
H50-40-10 & 50 & 40 & 10 \\
H60-40-0 & 60 & 40 & 0 \\
\hline
\end{tabular}

of the particles was performed in a mixing tank, where the fine particles were added first and then water and the binders. Samples were sent to XRD on a PANalytical's AXIOX MAX and NDIR spectroscopy on a Quimitron's QCS-20 I 0 at Niobras chemical lab.

\subsection{Fe-Nb Briquettes Characterization}

\subsection{Shatter test}

Shatter test (or Impact Resistance Test or Drop Test) determines the briquette strength to withstand repeated drops, simulating impacts that occur naturally during handling and transportation. According to Carvalho and Brink [6] for uncured briquettes, 3 drops from $30 \mathrm{~cm}$ are considered a reasonable value. Eighteen briquettes from each type were submitted to shatter tests from $30,50,75,100,125$ and I $50 \mathrm{~cm}$ height.

\subsubsection{Uniaxial compression and tension}

A compressive load was applied direct to the briquette using a hydraulic press until the briquette rupture, as described by the Brazilian Association of Technical Standards (ABNT) NBR 12767/92 [I I]. To evaluate the tension resistance the method created by Professor Lobo Carneiro was used. This method calculates the tensile strength through a diametric compression test (Falcão and Soares [12]). Altogether twenty-six briquettes where used in both tests). Briquettes manufactured by Renova could not be tested using Lobo Carneiro test because of their geometry.

\subsubsection{Water absorption}

According to Cunha et al. [13] in this test, briquettes must be complete submerged in water for 24 hours. After this time, the briquettes must be removed from water and put to rest in room temperature for 10 minutes in order to remove the water layer adsorbed in their surface and then weighted. Then they must be dried in a drying oven at $80^{\circ} \mathrm{C}$ for 2 hours. In order to return the briquettes to room temperature they must be put to rest again for 20 minutes and weighted again. The amount of water that is absorbed by the briquette is important when the briquettes can be stored in open areas [6]. Altogether forty-eight $\mathrm{Fe}-\mathrm{Nb}$ briquettes where tested.

\subsubsection{Thermal shock}

The shock temperature can be defined as the maximum temperature that the briquette resist without lose more than $10 \%$ of its mass, without collapse or explode, during a fast temperature elevation. Briquettes were weighted and placed in a steel cylinder with holes in the lid and placed in a muffle oven with temperatures ranging from 300 to $550^{\circ} \mathrm{C}$ for 20 minutes. The briquettes were removed from the oven and let to rest in room temperature before a new 
weighing. The maximum temperature reached was the temperature when the briquette start to combust (defined as ignition temperature). Sixty briquettes where submitted to thermal shock test.

\subsubsection{Brinell hardness test}

The diameter of the tungsten carbide indenter used was $10 \mathrm{~mm}$ with loads ranging from 500 to $3000 \mathrm{~kg}$. During the test, the load was maintained constant for $30 \mathrm{~s}$ (Callister and Rethwisch [14]). Twenty-five briquettes where used measure the Brinell hardness.

\subsubsection{Tumbler drum test}

The tumbler drum test is derived from the R-556 of the MICUM standard for coke of the International Organization for Standardization (ISO). In this test, $1.5 \mathrm{~kg}$ of briquettes were placed in a steel test drum $(29 \mathrm{~cm}$ long and $30.5 \mathrm{~cm}$ diameter) fitted with four steel angles with $6.5 \mathrm{~cm}$ wider, fixed lengthwise inside the drum. The drum was rotated at $25 \mathrm{rpm}$ for eight minutes (200 revolutions in total). The material was then sieve-analysed to measure the size reduction that has occurred.

\section{RESULTS AND DISCUSSION}

\section{I Characterization of Fe-Nb Fines}

Figure 4 shows the granulometric analyse of the $\mathrm{Fe}-\mathrm{Nb}$ fine particles before the agglomeration. It is possible to notice that particles type A (under $2 \mathrm{~mm}$ ) and type $B$ (between I and $5 \mathrm{~mm}$ ) were well classified, fitting into their label. On the other hand, particles type $C$ (between 3 and $15 \mathrm{~mm}$ ) where actually smaller than expected. In fact, particles type $C$ were smaller than $7 \mathrm{~mm}$.

Table 2 shows the chemical results of the $\mathrm{Fe}-\mathrm{Nb}$ fine particles compared to a standard composition of the alloy as expected by the steelmaking market. Due to mineral associations at Niobras mine, the main contaminants are $\mathrm{P}, \mathrm{Ti}$ and $\mathrm{Mn}$. All three fine particles types are chemically adequate for steelmaking.

\subsection{Fe-Nb Briquettes Characterization}

\subsection{Shatter test}

Figure 5 summarizes the average resistance of the briquettes regarding the number of drops at different heights supported in the shatter test. It was possible to notice that cylindrical briquettes manufactured by Höganäs had a high tendency in complete fragment themselves after a few drops, even from the smallest heights. The higher resistance was observed for the briquette R-0-100-0. For heights higher than $100 \mathrm{~cm}$ all type of briquettes showed a similar behaviour, losing $5 \%$ or more of their initial mass in less than 10 drops.

\subsubsection{Uniaxial compression and tension}

Figure 6 shows the average results found in the uniaxial compression test for the four types of briquettes and the results for the uniaxial tension test for the cylindrical

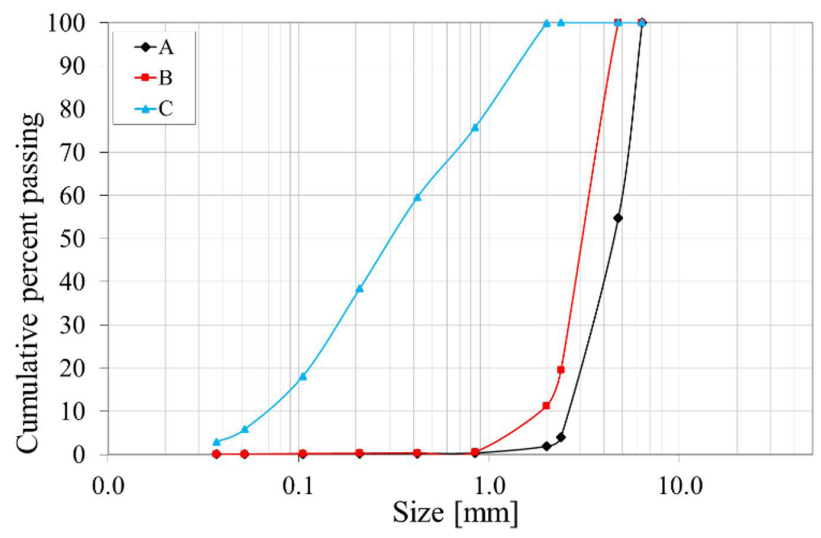

Figure 4. Granulometric analyse of the $\mathrm{Fe}-\mathrm{Nb}$ fine mixes before the agglomeration. Type A (under $2 \mathrm{~mm}$ ), type B (between I and $5 \mathrm{~mm}$ ), and type $C$ (between 3 and $15 \mathrm{~mm}$ ).

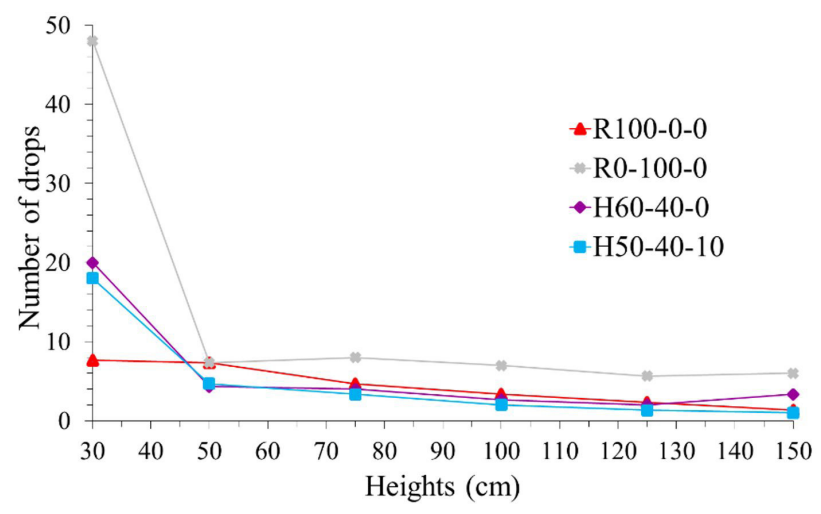

Figure 5. Average shatter test results.

Table 2. Standard Fe-Nb composition and chemical composition of the fine particles

\begin{tabular}{ccrrr}
\hline \multirow{2}{*}{$\begin{array}{c}\text { Elements } \\
\text { (\%) }\end{array}$} & \multicolumn{4}{c}{ TYPE } \\
\cline { 2 - 5 } Standard & \multicolumn{1}{c}{ A } & \multicolumn{1}{c}{ B } & \multicolumn{1}{c}{ C } \\
\hline Nb* & $62-67$ & 64.56 & 65.17 & 65.25 \\
P* $^{*}$ & $<0.20$ & 0.15 & 0.17 & 0.15 \\
Fe* $^{*}$ & $25-30$ & 29.18 & 28.65 & 27.97 \\
Ti* $^{*}$ & $<1.00$ & 0.33 & 0.25 & 0.24 \\
Mn* $^{*}$ & $<0.50$ & 0.30 & 0.30 & 0.35 \\
Si $^{*}$ & $<3.00$ & 2.95 & 2.85 & 2.68 \\
Ta* $^{*}$ & $<0.50$ & 0.31 & 0.31 & 0.29 \\
Pb* $^{*}$ & $<0.20$ & 0.19 & 0.19 & 0.18 \\
Al* & $<1.00$ & 0.40 & 0.31 & 0.23 \\
C** & $<0.15$ & 0.14 & 0.14 & 0.13 \\
S** & $<0.15$ & 0.07 & 0.09 & 0.07 \\
\hline
\end{tabular}

$*$ XRD results and $* *$ NDIR results. 
briquettes. Briquettes manufactured by Höganäs obtained the higher results and this could be related with their geometry, once the cylindrical shape provides a better contact surface with the hydraulic press. The soap shaped briquettes had a poor contact surface, with normally one contact point and not a proper surface. Regarding the tension resistance, the cylindrical briquettes showed a resistance around $50 \%$ of the compression resistance. Compared with other materials this is a high value. Concrete, for example, shows tension resistance around $10 \%$ of the compression resistance.

\subsubsection{Water absorption}

Briquettes supported the immersion in water for 48 hours without any physical degradation or decomposition, remaining almost intact. Figure 7 shows the water absorption test results. It is possible to notice that all briquettes had their mass increased at least by $1 \%$ after 48 hours of immersion in water. Although the Renova briquettes had the high mass gain during the test, the briquettes behaviour was quiet unusual, since a plateau was expected describing a water saturation level. Explanations for this behaviour could be the hydration of the binder agents, such as the iron powder, or chemical reactions of the $\mathrm{Fe}-\mathrm{Nb}$ alloy with water.

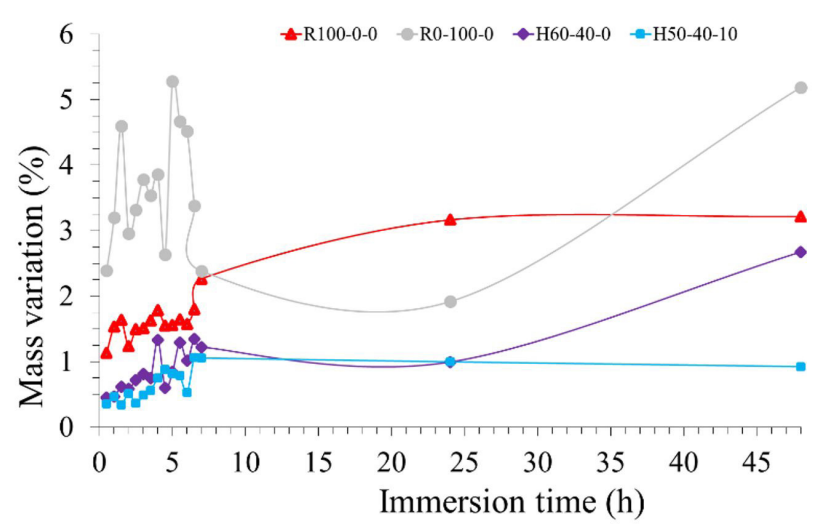

Figure 6. Average uniaxial breakdown load (compression and tension) results.

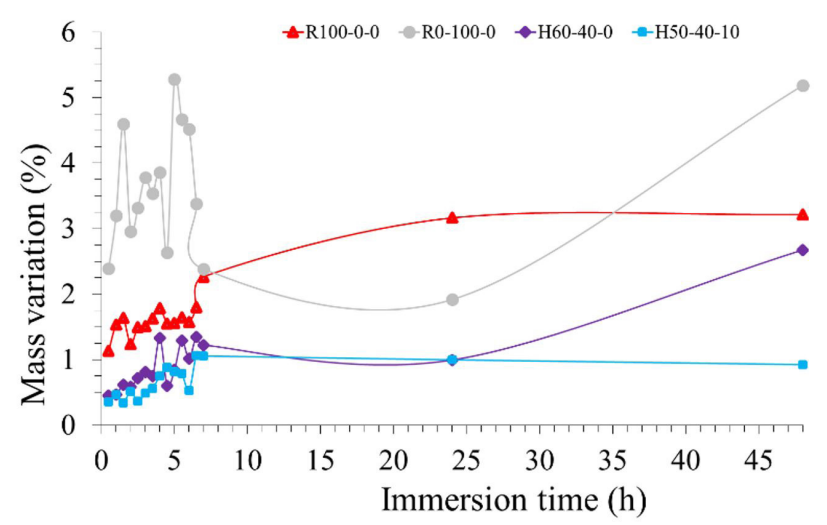

Figure 7. Average water absorption test results.

\subsubsection{Thermal shock}

Since the Fe-Nb alloy was produced through aluminothermy, it was expected that all combustible material were complete consumed in that stage, but that was not the case. Every test performed at temperatures above $600^{\circ} \mathrm{C}$ ignited the briquettes. The flame produced remained burnt around 12 hours after the briquettes ignition. Figure 8 shows the average fragments percentage generated at different temperatures during the tests. No clear pattern could be observed between the briquettes behaviour regarding the fragments generation during the test. It is possible to highlight that the briquette RI00-0-0 supported $100^{\circ} \mathrm{C}$ more than the briquette $\mathrm{R} 0-100-0$ and $\mathrm{H} 50-40-10$ before they start combusting.

\subsubsection{Brinell hardness test}

Figure 9 shows the average results found in the Brinell test. As expected, the found results were quite low for all briquettes since they are agglomerated materials, formed mainly by the mechanical forces. Therefore, their indentation resistance must be low and, in this case, compatible with a polymeric material or minerals with Mohs hardness bellow gypsum.

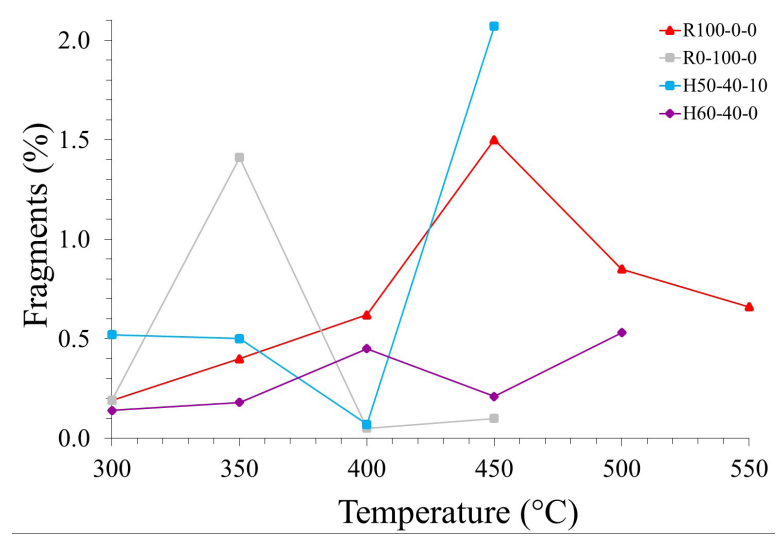

Figure 8. Average briquettes fragments percentage generated at different temperatures.

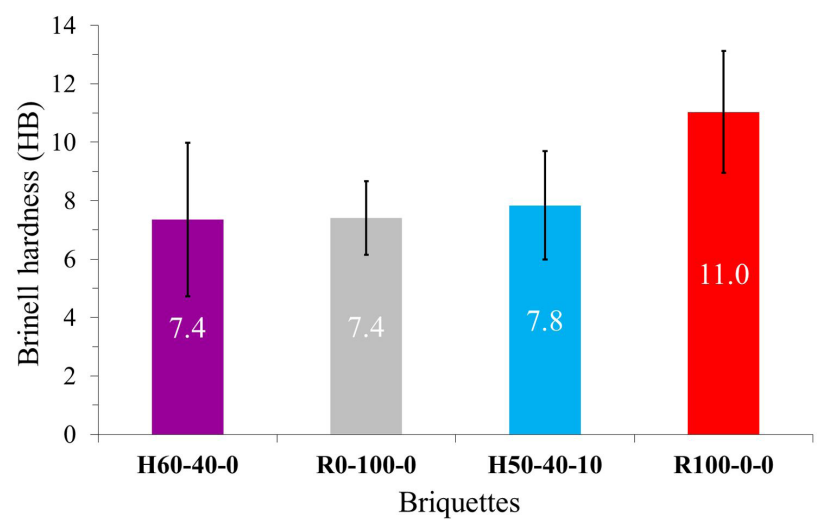

Figure 9. Briquettes average Brinell hardness. 


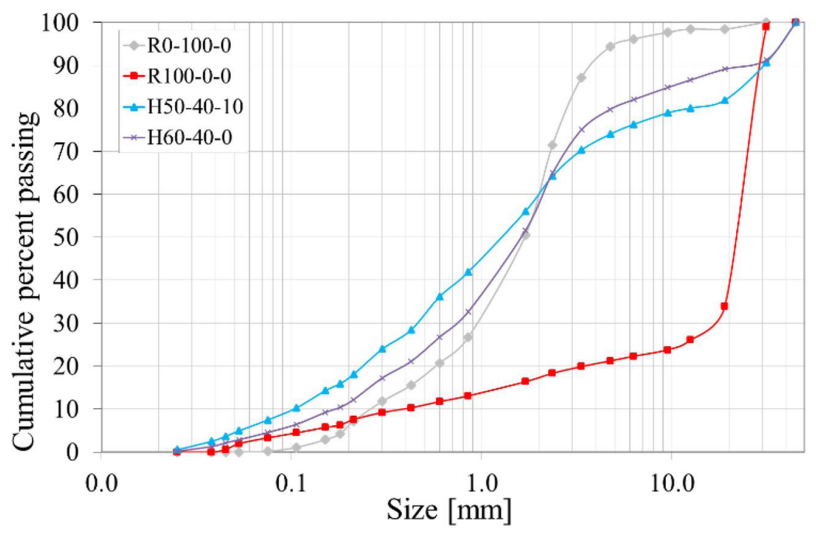

Figure 10. Granulometric analyse of the briquettes after the tumbler test.

\subsubsection{Tumbler drum test}

Figure 10 shows the average granulometric analyse of the briquettes after the tumbler test. Considering the material passing in sieve with aperture $3 / 4$ " (or $19 \mathrm{~mm}$ ) only the briquette R I00-0-0 had a considerable resistance, producing $34 \%$ of its mass bellow this aperture. This result is consistent with the Brinell hardness result, since the RI00-0-0 was the briquette hardener one and the tumbler test evaluate the shear resistance of the material. The other briquettes had results above $80 \%$ of passing $(98.5 \%$ for RO- I00-0, 89.2\% for $\mathrm{H} 60-40-0$ and $81.9 \%$ for $\mathrm{H} 50-40-\mathrm{I} 0$ ).

\section{CONCLUSIONS}

Regarding the shatter test, all tested briquettes succeeded in the test considering the literature parameters. However, the found results were heterogeneous and a trend could not be stablished. Briquettes manufactured by Höganäs (cylinders) showed results slightly more homogeneous than the ones manufactured by Renova.

It was possible to notice in the uniaxial compression test that briquettes manufactured by Höganäs had better results, however showing a standard deviation higher than Renova's briquettes. This fact may be due to the geometry of them, once Höganäs' briquettes have a better stress distribution because of their cylindrical shape. The same briquettes showed a higher than expected uniaxial tension resistance.

All briquettes were able to resist the water absorption test retaining their shapes. For higher immersion time Höganäs' briquettes complete disintegrate, not retaining either shape or mechanical resistance. In some briquettes, immersed for 48 hours, it was possible to notice some oxidation spots on them. Only one briquette (R0-100-0) did not gain mass after the test.

Regarding the thermal shock, all briquettes were successful. Although it was not possible to stablish a trend from the obtained results, the briquettes ignition temperature was stablished bellow $550^{\circ} \mathrm{C}\left(450^{\circ} \mathrm{C}\right.$ for RO- $100-0$ and $\mathrm{H} 50-40-10,475^{\circ} \mathrm{C}$ for $\mathrm{H} 60-40-0$, and $550^{\circ} \mathrm{C}$ for RI00-0-0).

Briquettes showed a low Brinell hardness, which was expect once they were only agglomerated through mechanical stress, without the addition of any kind of chemical binder. At last, regarding the tumbler test all types of briquettes generated fine particles during the test. Although the briquette R I00-0-0 showed a higher resistance compared with the others.

Summarizing the found results both fabrication methods can be industrially adopted for briquette production with parameters acceptable by the steelmaking marketing. All fine particle blends tested were successful regarding the briquette chemical composition and mechanical properties. It was not possible to choose one manufacture method between the two tested because the found results were quite different. In the end, the authors suggest the adoption of the cylindrical briquettes manufactured by Höganäs as the best choice, combining good results in most of the tests and the lower manufacture costs.

\section{Acknowledgements}

The authors thank financial support from the Brazilian agencies CNPq, CAPES, FAPEG and FUNAPE. In addition, we like to thank Niobras for the samples donation and chemical analyses and Federal University of Goiás.

\section{REFERENCES}

I Mendes MWD. Obtaining Nb powders from the thermal aluminum reduction with plasma ignition [dissertação]. Natal: Universidade Federal do Rio Grande do Norte; 2005.

2 Sousa RMF, Fernandes LE, Guerra W. Niobium. Química Nova na Escola. 2013;35:68-69.

3 Damasceno EC. Availability, supply and demand of ores for metallurgy. Rio de Janeiro: CETEM/MCT; 2006. Série Estudos e Documentos - CETEM/MCT.

4 USGS Science for a Changing World. Niobium (columbium) and tantalum statistics and information. USA: USGS; 2017 [cited 2017 Aug 3]. Available at: https://minerals.usgs.gov/minerals/pubs/commodity/niobium/ 
Silva et al.

5 Companhia Brasileira de Metalurgia e Mineração. Situação de exploração e exportação de nióbio. Araxá: CBMM; 2017 [cited 2017 Aug 3]. Available at: https://www2.camara.leg.br/atividade-legislativa/comissoes/comissoespermanentes/cme/audiencias-publicas/2017/30-08-20I7-situacao-de-exploracao-e-exportacao-de-niobio/ CBMM_30_08.pdf

6 Carvalho EA, Brinck V. Aglomeração: Parte I: briquetagem. In: Luz AB, Sampaio JA, França SCA. Tratamento de minérios. 5. ed. Rio de Janeiro: CETEM/MCT; 2010.

7 Moraes SL, Kawatra SK. Evaluation of the use of combinations of binders in the pelletization of magnetite concentrate by balling drum technology. Tecnologica em Metalurgia, Materiais e Mineração. 201 I;8(3): 168- 173.

8 Telles VB, Espinosa DCR, Tenório JAS. Iron ore sinter production using electric arc furnace dust as raw material. Tecnologica em Metalurgia, Materiais e Mineração. 20I3; I0(I):72-77.

9 Lucena DA, Medeiros RD, Fonseca UT, Assis PS. Fine charcoal agglomeration and its feasibility for blast furnace usage and for energy generation. Tecnologia em Metalurgia e Materiais. 2008;4(4): I-6.

I0 Silva AC, Silva EMS, Barros MR, Marinho DY. Limestone fines reuse for agriculture through briquetting. Tecnologica em Metalurgia, Materiais e Mineração. 2016;13(4):365-372.

II Associação Brasileira de Normas Técnicas. NBR I2767/92 - Rochas para revestimento - Determinação da resistência à compressão uniaxial. Rio de Janeiro: ABNT; 1992.

12 Falcão MFB, Soares JB. Considerations on the diametrical compression test in the study of paving materials. In Anais do XVI Congresso de Pesquisa e Ensino em Transportes; 2002; Natal, RN, Brasil. Natal: ANPET; 2002.

13 Cunha AF, Mol MPG, Martins ME, Assis PS. Characterization, improvement and recycling of careloads generated in steel processes. REM Revista Escola de Minas. 2006;59(I): I I I- I I6.

I4 Callister WD, Rethwisch DG. Materials science and engineering: an introduction. 9th ed. USA: John Wiley \& Sons; 2013.

Received: 15 Apr. 2018

Accepted: 26 Apr. 2019 